\title{
The importance of the M470V polymorphism
}

\section{M470V polimorfizminin önemi}

\author{
Tanju ÇELIIK ${ }^{1}$, Ramazan GÜNEŞAÇAR ${ }^{2}$, Ali BALCI ${ }^{3}$, Sule ÜNAL ${ }^{4}$, Güliz ALDİC ${ }^{1}$, Harika ESKİCí ${ }^{4}$, \\ Nigar ATILGAN ${ }^{1}$, Sibel ELMACIOGLU ${ }^{1}$, Murat TUTANC ${ }^{1}$, Demet CAN ${ }^{5}$
}

${ }^{1}$ Mustafa Kemal Üniversitesi, Tıp Fakültesi, Hatay

${ }^{2}$ Kahramanmaras Sütçüimam Üniversitesi, Genetik Bilim Dall, Kahramanmaras

${ }^{3}$ Dokuz Eylül University, Tip Fakültesi, Radyoloji Ana Bilim Dalı, İzmir

${ }^{4}$ Antakya Devlet Hastanesi, Hatay

${ }^{5}$ Behçet Uz Çocuk Hastalıkları ve Cerrahisi Eğitim ve Araştırma Hastanesi, Allerji ve Solunum Kliniği, İzmir

\begin{abstract}
Objective: Several hundreds of cystic fibrosis transmembrane conductance regulator (CFTR) variants have been reported, however it is not known whether which one of them was causing the disease of cystic fibrosis $(\mathrm{CF})$ or not. Information about CFTR genes carrying the M470 or the V470 allele are interesting. In this study, we aimed to investigate the clinical importance of M470V mutation in Antiochia region.

Methods: A case- control study consisted of 145 children from whom CF gene study was requested because of recurrent respiratory tract infections, growth failure, chronic diarrhea and constipation. The parameters of patients with positive mutation were compared with negative ones as for gender, age, height, weight, annual number of upper and lower respiratory tract infections, parental consanguinity, sibling death, clinical and laboratory parametres.

Results: In 63 of 145 patients $(43.4 \%)$, heterozygous mutation, in 16 (11\%) of them homozygous mutation was detected. All of the patients with mutation group had M470V mutation. The sweat test results of all patients were within normal limits. Mean age of those patients were $41.21 \pm 39.8$ (min: 6 max: 192) months and $30(38 \%)$ of them were girls. Thirty percent of the patients with mutation $(n=17.7)$ had a familial history of cystic fibrosis, 2 a history of sibling death. In the mutation group, only annual number of infections, skin dryness, loss of weight, level of IgG and IgM were significantly higher $(\mathrm{p}<0.05)$.

Conclusion: It was concluded that in $\mathrm{M} 470 \mathrm{~V}$ positive cases, the disease may cause clinical symptoms without affecting sweat test results, with less gastrointestinal but more respiratory symptoms, causing a more prominent loss of weight.
\end{abstract}

Keywords: Child, cystic fibrosis, M470V

\section{$\ddot{0 Z z}$}

Amaç: Kistik fibroz transmembran regulatör (CFTR) geni ile ilgili yüzlerce varyant bildirilmesine karşın, hangisinin kistik fibrozis (CF) hastalığına yol açtığı bilinmemektedir. CFTR geninin M470 ve V470 alelleri ile ilgili bilgiler ilgi çekicidir. Bu çalışmada, Antakya bölgesinde M470V mutasyonunun klinik önemi araştırılmıştır.

Yöntem: Çalışmaya, yineleyen solunum yolu enfeksiyonları, büyüme geriliği, kronik diare ya da konstipasyon nedeniyle CF genetik analizi istenen 145 çocuk alınmıştır. Genetik mutasyonu pozitif ve negatif hastalar cins, boy, kilo, yıllık üst ve alt solunum yolu enfeksiyon sayısı, akraba evliliği, kardeş ölümü, klinik ve laboratuvar parametreleri yönünden karşılaştırılmıştır.

Bulgular: Yüz kırk beş hastanın 63'ünde $(\% 43,4)$ heterozigot, 16'sında (\%11) homozigot mutasyon saptanmıştır. Mutasyon saptanan hastaların tümünde M470V mutasyonu vardır. Tüm hastaların ter testleri normal sınırlarda bulunmuştur. Hastaların ortalama yaşı 41,21 $\pm 39,8$ (min: 6 max: 192) ay olup, 30'u (\%38) kızdır. Mutasyon saptanan hastaların 17,7'sinde (\%32) ailede CF öyküsü, 2'sinde kardeş ölümü öyküsü vardır. Yıllık enfeksiyon sayısı, deri kuruluğu, kilo kaybı, IgG ve IgM düzeyleri anlamlı olarak yüksek bulunmuştur $(\mathrm{p}<0,05)$.

Sonuç: M470V mutasyonunun ter testi sonuçlarını etkilemeden daha sık solunum daha nadir gastrointestinal sistem olmak üzere CF klinik semptomlarına ve belirgin kilo kaybına neden olduğu düşünülmüştür.

Anahtar kelimeler: Çocuk, kistik fibrozis, M470V

Alındığı tarih: 07.02.2017

Kabul tarihi: 26.04.2017

Yazışma adresi: Prof. Dr. Demet Can, Behçet Uz Çocuk Hastalıkları ve Cerrahisi Eğitim ve Araştırma Hastanesi, Allerji ve Solunum Kliniği, İzmir

e-mail: ddcan15@hotmail.com 


\section{INTRODUCTION}

Cystic fibrosis (CS) is a terminal disease characterized with dark, sticky mucus secretion from the exocrine glands showing autosomal recessive inheritance ${ }^{(1)}$. The gene causing the disease is localized on the 7th chromosome. The spread mutation detected in $\mathrm{CF}$ is $\Delta \mathrm{F} 508$ and over 1500 mutations have been determined ${ }^{(2,3)}$.

Several hundreds of cystic fibrosis transmembrane conductance regulator (CFTR) variants have been reported, it is not known whether they are causing CF or not. One of "CFTR mutations which were associated with polymorphisms" is M470. The most interesting finding about the different patterns was CFTR genes carrying the M470 or the V470 allele. M470 and the combined $\mathrm{V}$ frequency are seen in the subSaharan Africa. Although there was polymorphism, M470V may cause clinical issues, such as congenital bilateral absence of the vas deferens in Chinese males $(2,4,5)$.

The carrier rate of $\mathrm{CF}$ in the white race is stated as $1 / 25$ and the incidence of live birth as 1/2500-3000. The frequency of the disease show significant differences between ethnical groups and countries due to the autosomal recessive inheritance because of consanguineous marriage, ${ }^{(1,5-7)}$. In this study, we aimed to investigate the clinical importance of M470V mutation in the Antiochia region (ancient commercial center and capital of Syria; an early center of Christianity) a region with frequent consanguineous marriages due to ethnical reasons.

\section{MATERIALS and METHODS}

The study was designed as a case-control study. The study group (mutation positive group) consisted of 79 children with mutations out of 145 children who had undergone CF gene study because of recurrent respiratory tract infections, growth failure, chronic diarrhea and constipation.

\section{Genetic analysis}

DNA was isolated from whole blood samples in EDTA using a commercially available DNA extracti- on kit (RTA Lab, Ltd., Sti, Turkey). PCR amplification of exons 7, 10 and 11 in the cystic fibrosis conductance transmembrane regulator (CFTR) gene was performed using gene specific primers. Each primer was used to perform both genomic DNA amplification and sequencing reactions. PCR was performed using a total volume of $25 \mu \mathrm{l}$, containing $100 \mathrm{ng}$ of genomic DNA, $12.5 \mu$ of $2 x$ reaction buffer (GML SeqFinder Sequencing System, Switzerland), 5 pmol of each primer. After an initial denaturation step at $95^{\circ} \mathrm{C}$ for 10 mins, samples were subjected to 35 cycles of PCR at $95^{\circ} \mathrm{C}$ for 30 secs at $59^{\circ} \mathrm{C}$ for 90 secs, and at $72^{\circ} \mathrm{C}$ for 60 secs with a final extension step at $72^{\circ} \mathrm{C}$ for 7 mins. Amplified products were verified by electrophoresis using $2 \%$ agarose gel and also cyclesequencing reactions were performed in both forward and reverse directions in terminator ready reaction mixture containing Big Dye Terminator v3.1 Cycle Sequencing Kit (Applied Biosystems, USA) and submitted to 25 cycles at $96^{\circ} \mathrm{C}$ for $10 \mathrm{secs}, 50^{\circ} \mathrm{C}$ for 5 secs, $60^{\circ} \mathrm{C}$ for 4 mins. After the purification of cycle sequencing products, $5 \mu \mathrm{l}$ of marked and purified DNA were analysed by capillary electrophoresis on an ABI PRISM 3130 Genetic Analyser (Applied Biosystems, Forster city, CA, USA). The mutation was confirmed via sequencing of the anti-sense DNA strand, which was performed twice.

\section{Study design}

The cases were separated into 2 groups as mutation negative and mutation positive according to their gene mutation results. The admission complaints of the cases were evaluated based on physical examination and laboratory findings.

Gender, age, height, weight, history of meconium ileus, prolonged neonatal jaundice, skin findings, annual number of upper and lower respiratory tract infections, parental consanguinity, sibling death, sibling with cystic fibrosis, family history of chronic constipation, acute pancreatitis were recorded. Physical examination findings such as nasal polyps, chronic sinusitis, complete blood count, routine biochemistry, serum levels of immunoglobulins, sweat test results, fecal fat, chest $\mathrm{X}$ ray and sinus radiology findings were recorded. 


\section{Statistical analyses}

Mean, median, standard deviation (SD) and range were computed for each domain of the CF in this reference population. Kolmogorov-Smirnov tests were used to test whether the CF domain scores showed a normal distribution. Analyses were separately performed for mutation groups. The Mann-Whitney test, chi-square tests, logistic regressions were used to assess potential differences between genders, analyses and different age-groups. Data were analyzed with SPSS version 15.0.

\section{RESULTS}

In 63 of 145 patients (\%43.4), heterozygous, and in 16 (\%11) cases homozygous mutations were detected. A total of 79 patients had M470V mutations. Mean age of those patients was $41.21 \pm 39.8$ (min: 6 max: 192) months and $30(\% 38)$ were girls and 49 (\%62) were boys. Seventeen (32.7\%) patients with mutation, and $5(18.5 \%)$ with negative mutation had a familial history of cystic fibrosis. There is no statistically significant difference between them $(p<0.05)$. Siblings of 2 patients with mutation were dead.

The recurrent respiratory tract infections (adenoiditis, tonsillitis, sinusitis, bronchitis and bronchopneumonia) of the cases were questioned. In the mutation group, only annual number of infections were significantly higher $(\mathrm{p}<0.01)$. There were respiratory tract complaints in $56(70.9 \%)$, gastrointestinal in 11 (13.9\%) and both respiratory and gastrointestinal system complaints and findings in $12(15.2 \%)$ cases.

When evaluated according to the gastrointestinal symptoms, past history of meconium ileus and neonatal jaundice stories was not significant in both groups. None of the cases were receiving pancreatic enzyme and enteric nutrition support. There was no significant difference between the two groups as for past history of chronic constipation and diarrhea.

When the cases were separated into groups according to their height percentiles, the patients were under 3. percentile $(n=17,21.5 \%)$ or within 3 . and 10 . percentiles $(n=28 ; 35.4 \%)$, and short stature was detected in a total of 45 cases $(57 \%)$. Besides body weights of the patients were under 3. percentile $(n=13 ; 16.5 \%)$ or within 3 . and 10 . percentiles $(n=26$; $32.9 \%)$ and a total of $39(49.4 \%)$ cases were detected. The patients with mutation had significantly low weight percentiles. Even though their height percentiles were lower, intergroup differences were statistically significant $(\mathrm{p}>0.05)$. Skin dryness was statistically significantly more frequent in mutation positive cases $(\mathrm{p}<0.01)$.

The sweat test results of all patients were within the normal limits. Chlorine levels in both groups were detected to be less than $60 \mathrm{mmol} / \mathrm{L}$.

Hemoglobin values of the whole group was detected as $11.43 \pm 1.1$ (min: 8,6 max:14) $\mathrm{mg} / \mathrm{dl}$, white blood cell count as $11 \pm 3.9 \times 103 / \mu 1$ (min: $5.1103 / \mu 1$, and max: $25.2103 / \mu 1)$, platelet count as $400 \pm 116.4 \mathrm{x}$ 103/ $\mu 1$ (min: 198x103/ $\mu 1$ max: 726x103/ $\mu 1$ ).

When we compared groups according to age, gender, white blood, hemoglobin, platelet, level of serum Ig E and Ig A results, there were no significant differences amongh groups.. In mutation group, level of serum $\operatorname{IgG}$ and $\operatorname{IgM}$ were significantly higher $(\mathrm{p}<0.05)$ (Table 1). In the mutation group the number of children with low weight, $\operatorname{IgA}$ deficiency and $\operatorname{IgE}$ excess was statistically significantly lower when compared with those without mutation $(\mathrm{p}<0.05),(\mathrm{p}<0.01)$ (Table 2).

Table 1. The clinical and laboratory characteristics of cases with respect to mutation groups.

\begin{tabular}{lccc}
\hline & $\begin{array}{c}\text { Mutation (+) } \\
\text { Group (n:52) } \\
\text { Mean+SD }\end{array}$ & $\begin{array}{c}\text { Mutation (-) } \\
\text { Group (n:27) } \\
\text { Mean } \pm \text { SD }\end{array}$ & p value \\
\hline Male & 23 & 7 & 0.09 \\
Female & 29 & 20 & \\
Age (months) & $38 \pm 36$ & $45 \pm 45$ & 0.4 \\
Hemoglobin & $10.3 \pm 1$ & $11.5 \pm 1$ & 0.4 \\
WBC & $10.9 \pm 3.9$ & $11 \pm 3.7$ & 0.9 \\
PLT & $400 \pm 13$ & $396 \pm 86$ & 0.8 \\
Ig A & $105 \pm 67$ & $80 \pm 47$ & 0.058 \\
Ig G & $884 \pm 27$ & $698 \pm 27$ & 0.04 \\
IgM & $103 \pm 33$ & $88 \pm 26$ & 0.02 \\
IgE & $179 \pm 25$ & $174 \pm 28$ & 0.9 \\
\hline
\end{tabular}

Average serum glucose values in the cases with low height and weight percentiles were detected to be significantly low in both groups $(\mathrm{p}<0.05)$. However, hypoglycemia or hyperglycemia was not detected. 
Table 1 . The clinical and laboratory characteristics of cases with respect to mutation groups.

\begin{tabular}{lcccc}
\hline Properties & $\begin{array}{c}\text { Mutation (+) } \\
\text { Group } \\
\text { n (\%) }\end{array}$ & $\begin{array}{c}\text { Mutation (-) } \\
\text { Group } \\
\mathbf{n}(\boldsymbol{\%})\end{array}$ & $\begin{array}{c}\text { Total } \\
\text { n }\end{array}$ & P value \\
\hline Short stature & $33(73.3)$ & $12(26.7)$ & 45 & 0.08 \\
Low weight & $30(76.9)$ & $9(23.1)$ & 39 & 0.03 \\
Ig A deficiency & $33(58.9)$ & $23(41.1)$ & 56 & 0.04 \\
Ig G deficiency & $0(0)$ & $1(100)$ & 1 & 0.3 \\
IgM deficiency & $0(0)$ & $1(100)$ & 1 & 0.3 \\
High IgE values & $30(85.7)$ & $4(14.3)$ & 35 & 0.001 \\
\hline
\end{tabular}

The glucose, SGPT, SGPT, BUN, creatinine, GGT, protein, albumin, sodium, potassium, chlorine, calcium, phosphorus, alkaline phosphatase, total bilirubin and direct bilirubin values checked in all of the cases were detected to be within the normal reference values in both groups.

Fecal fat was checked in the stool of all patients and fat in the stool of $5(9.6 \%)$ mutation positive cases were detected.

Abdominal USG was done on all patients, fullness and gall sludge in gall bladder was detected in 2 mutation positive cases.

\section{DISCUSSION}

Cystic fibrosis is caused by mutations in the CFTR (ABCC7) gene. The most common mutation is $\Delta F 508 d e l$, which accounts for approximately two thirds of all CFTR alleles in patients with $\mathrm{CF}$, with a decreasing prevalence from Northwest to Southeast Europe. The remaining third of alleles are substantially heterogeneous, with fewer than 20 mutations occurring at a worldwide frequency of more than $0.1 \%$. Some mutations can reach a higher frequency in certain populations, due to a founder effect in religious, ethnic or geographical isolates ${ }^{(8,9)}$.

In a study carried out in the European community, 1700 gene mutations were checked and a total of 80 different variations, 61 of which were previously detected. Three important CFTR haplotypes were known as poly-T, TG-repeats and the M470V polymorphisms. M470V polymorphism was studied in the sub-Saharan region and very high incidence rates were detected. It was stated that $\mathrm{V}$ allele may be sour- ced outside of Africa and may be from Europe or Asia ${ }^{(9,10)}$. M470 genes are the ancestral genes ${ }^{(11,12)}$. In our study, no mutations other than M470V gene mutations were detected. M470 gene mutation may be frequently detected because our region was known as Mesopotamia in the ancient times and was a part of the old world. Our region including Antioch (Antakya) which was the capital of Syrian province of Eastern Roman Empire may be effective in detection of the $\mathrm{V}$ allele which is known to be sourced from Europe or Asia.

CFTR mutations vary in their frequency and distribution in different populations. Very few mutations have a worldwide frequency above $0.1 \%$, but some can reach high prevalence in selected populations ${ }^{(13)}$. Thus Antioch region which is a region with frequent consanguineous marriages due to ethnical reasons was chosen.

Sweat chlorine test is still the golden standard in diagnosis of cystic fibrosis. Typical clinical findings and sweat test results support the diagnosis in the cases with cystic fibrosis. Genetic mutation detection is an important method which may affect the future life of the patient. Furthermore, polymorphism adds to the severity of the disease ${ }^{(14.15)}$. In our study, polymorphism was detected in $54.4 \%$ of the patients while no patient had positive sweat test.

Mutation analysis may be used for making a diagnosis of $\mathrm{CF}$ in individuals with a consistent clinical picture. CFTR mutations may: A. cause CF; B. be associated with CFTR-related disorders; C. have no clinical consequences; D. have unknown or uncertain clinical relevance.

M470V mutations were also added to the group without clinical symptoms. However, it is stated that pathogenic potentials of most mutations are not determined, mutation analysis will not end the contradiction and the clinician should act according to the clinical findings of the patient ${ }^{(9,16,17)}$. The children with M470V mutation detected in our study having clinical findings related to the disease support this view.

CF phenotype is affected from environmental factors and other genetic factors besides genotype. When homozygote and heterozygote classification of 
the patients was performed, a picture that changes from light lung diseases to serious severe lung diseases can be seen because the same classification can include different mutations. Similarly, it may come with chronic pancreatitis or repeating acute pancreatitis, sclerosing cholangitis or it may not give any symptoms ${ }^{(18,19)}$.

If there is $0-1$ gene mutation positivity was detected at the time of diagnosis and during follow up of $\mathrm{CF}$, there should be clinical and laboratory information exchange and their results should be especially considered together with the family characteristics of the patient, ethnical characteristics, frequency and test results shall be evaluated and followed as a whole. If there is suspicion, rare mutations shall be scanned in terms of carriership ${ }^{(16)}$. Case-control group with 0-1 gene mutation cases were included in this study. Even though definite limits cannot be shown, a patient profile with normal sweat test, characterized with frequently repeating infections and respiratory system involvement being in the forefront appeared.

The studies carried out have stated that the M470V mutation usually doesn't cause clinical findings ${ }^{(20,21)}$. However, M470V may cause clinical issues, such as congenital bilateral absence of the vas deferens in Asian males ${ }^{(4,22)}$. Also Kutuk et al. ${ }^{(23)}$ reported a case with jejunoileal atresia which is an intestinal sign of CF from Kayseri, Turkey. In our study, we would like to emphasize that especially the upper respiratory tract infections are seen more commonly in these cases. Another study (Algerian cystic fibrosis families) detected 1609delCA and the M470V polymorphisms in a child with severe CF findings ${ }^{(24)}$.

A study conducted in England and Wales regions retrospectively examined the records of the patients who died because of CF between the years of 1959 and 2008. It was stated that the male patients and the patients with high socio-economic level die sooner ${ }^{(25)}$. Due to the fact that pediatric cases were included in this study and that there were no severe cases, we didn't have any exiğted cases during the 1 year of observation period.

\section{CONCLUSION}

M470V positive cases were detected as a result of the genetic analysis carried out with CF suspicion in an ethnical region. The disease may cause clinical symptoms without affecting sweat test results, with less gastrointestinal but more respiratory symptoms, causing a more prominent loss of weight, and higher levels of immunoglobulin due to more frequent infections. As a result, this study which was performed in a closed society implicated the importance of M470V polymorphism in CF.

\section{Competing interests}

The authors have not declared any competing interests.

\section{Author's contributions}

TÇ, RG and SU performed the statistical analysis and wrote the manuscript. NA was the main supervisor and designed the study together with TÇ. HE $\mathrm{AB}, \mathrm{GA}$ DC and TÇ collected the data and drafted the manuscript. NA guided the statistical, laboratory analyses and study protocol. All other authors are involved in optimization of the study protocol, supervision of data collection, writing of the manuscript and critically revising it for important intellectual content. All authors have read and approved the final manuscript and declare that they have nothing to declare.

\section{Acknowledgement}

The authors would like to thank all the children, adolescents and their families for their cooperation.

\section{Role of funding}

The authors have declared that they had not received any financial support.

\section{REFERENCES}

1. Cialdella P, Carella F. Hypervitaminosis D: case report of pediatric osteoporosis secondary to cystic fibrosis. Clin Cases Miner Bone Metab 2011;8(3):66-8.

2. Hoelen H, Kleizen B, Schmidt A, Richardson J, Charitou P, et al. The Primary Folding Defect and Rescue of $\Delta F 508$ CFTR Emerge during Translation of the Mutant Domain. 
PLOS ONE 2010;5(11):e15458.

https://doi.org/10.1371/journal.pone.0015458

3. Zielenski J. Genotype and phenotype in cystic fibrosis. Respiration 2000;67:117-33.

https://doi.org/10.1159/000029497

4. Ni WH, Jiang L, Fei QJ, Jin JY, Yang X, Huang XF. The CFTR polymorphisms poly-T, TG-repeats and M470V in Chinese males with congenital bilateral absence of the vas deferens. Asian J Androl 2012;14(5):687-90. https://doi.org/10.1038/aja.2012.43

5. Mueller C, Flotte TR. Gene therapy for cystic fibrosis. Clin Rev Allergy Immunol 2008;35:164-178. https://doi.org/10.1007/s12016-008-8080-3

6. Rowntree RK, Harris A. The phenotypic consequences of CFTR mutations. Ann Hum Genet 2003;67:471-485. https://doi.org/10.1046/j.1469-1809.2003.00028.x

7. Riordan JR. CFTR function and prospects for therapy. Annu Rev Biochem 2008;77:701-726. https://doi.org/10.1146/annurev.biochem.75.103004.142532

8. Castellani C, Cuppens H, Macek M Jr, Cassiman JJ, Kerem $\mathrm{E}$, et al. Consensus on the use and interpretation of cystic fibrosis mutation analysis in clinical practice. J Cyst Fibros 2008;7(3):179-96. https://doi.org/10.1016/j.jcf.2008.03.009

9. Pompei F, Ciminelli BM, Bombieri C, Ciccacci C, Koudova M, Giorgi S. Haplotype block structure study of the CFTR gene. Most variants are associated with the M470 allele in several European populations. Eur J Hum Genet 2006;14(1):85-93.

10. Huang Q, Ding W, Wei MX. Comparative analysis of common CFTR polymorphisms poly-T, TG-repeats and M470V in a healthy Chinese population. World $J$ Gastroenterol 2008;14(12):1925-30. https://doi.org/10.3748/wjg.14.1925

11. Tucker SJ, Tannahill D, Higgins CF. Identification and developmental expression of the Xenopus laevis cystic fibrosis transmembrane conductance regulator gene. Hum Mol Genet 1992;1:77-82. https://doi.org/10.1093/hmg/1.2.77

12. Wine JJ, Glavac D, Hurlock G. Genomic DNA sequence of Rhesus (M. mulatta) cystic fibrosis (CFTR) gene. Mamm Genome 1998;9:301-305. https://doi.org/10.1007/s003359900753

13. Macek M Jr, Mackova A, Hamosh A, Hilman BC, Selden RF, et al. Identification of common cystic fibrosis mutations in African-Americans with cystic fibrosis increases the detection rate to $75 \%$. Am J Hum Genet 1997;60:1122-1127.

14. Groman JD, Hefferon TW, Casals T, Bassas L, Estivill X, et al. Variation in a repeat sequence determines whether a common variant of the cystic fibrosis transmembrane conductance regulator gene is pathogenic or benign. Am J Hum Genet 2004; 74:176-179. https://doi.org/10.1086/381001

15. Chillon M, Casals T, Mercier B, Bassas L, Lissens W, et al.
Mutations in the cystic fibrosis gene in patients with congenital absence of the vas deferens. N Engl J Med 1995;332:14751480 . https://doi.org/10.1056/NEJM199506013322204

16. Dequeker E, Stuhrmann M, Morris MA, Casals T, Castellani $\mathrm{C}$, et al. Best practice guidelines for molecular genetic diagnosis of cystic fibrosis and CFTR-related disorders--updated European recommendations. Eur J Hum Genet 2009; 17(1):5165. https://doi.org/10.1038/ejhg.2008.136

17. De Boeck K, Wilschanski M, Castellani C, Taylor C, Cuppens $\mathrm{H}$, et al. Cystic fibrosis: terminology and diagnostic algorithms. Thorax 2006;61:627-635. https://doi.org/10.1136/thx.2005.043539

18. Girodon E, Sternberg D, Chazouilleres O, Cazeneuve C, Huot D, et al. Cystic fibrosis transmembrane conductance regulator (CFTR) gene defects in patients with primary sclerosing cholangitis. J Hepatol 2002;37:192-197. https://doi.org/10.1016/S0168-8278(02)00161-7

19. Corleto VD, Gambardella S, Gullotta F, D'Apice MR, Piciucchi M, et al. New PRSS1 and common CFTR mutations in a child with acute recurrent pancreatitis, could be considered an "Hereditary" form of pancreatitis? BMC Gastroenterol 2010;10:119. https://doi.org/10.1186/1471-230X-10-119

20. Ratjen F, Döring G. Cystic fibrosis. Lancet 2003;361(9358):681-9. https://doi.org/10.1016/S0140-6736(03)12567-6

21. Bombieri C, Giorgi S, Carles S, de Cid R, Belpinati F, et al. A new approach for identifying non-pathogenic mutations. An analysis of the cystic fibrosis transmembrane regulator gene in normal individuals. Hum Genet 2000;106(2):172-8. https://doi.org/10.1007/s004390051025

22. Radpour R, Gourabi H, Gilani MA, Dizaj AV, Rezaee M, Mollamohamadi S. Two novel missense and one novel nonsense CFTR mutations in Iranian males with congenital bilateral absence of the vas deferens. Mol Hum Reprod 2006;12(11):717-21. https://doi.org/10.1093/molehr/gal077

23. Kutuk MS, Balta B, Doganay S, Guzel M, Ozgun MT. Prenatal diagnosis of intestinal volvulus in a foetus with homozygous M470V cystic fibrosis gene polymorphism. $J$ Obstet Gynaecol 2015;35:522-5. https://doi.org/10.3109/01443615.2014.979779

24. Loumi O, Cuppens H, Bakour R, Benabadji M, Baghriche M, et al. An Algerian child homozygous for the M470V polymorphism and for a deletion of two nucleotides in exon 10 of the CFTR gene, shows severe cystic fibrosis symptoms. Genet Couns 1992;3(4):205-7.

25. Barr HL, Britton J, Smyth AR, Fogarty AW. Association between socioeconomic status, sex, and age at death from cystic fibrosis in England and Wales (1959 to 2008): cross sectional study. BMJ 2011;343:d4662. https://doi.org/10.1136/bmj.d4662 